\title{
World's Agricultural Production and Trade: Food Security at Stake?
}

\author{
Miklós Somai
}

Institute of World Economics, Centre for Economic and Regional Studies, Hungarian Academy of Sciences, Budaörsi út 45, 1112 Budapest, 1535 Budapest Pf. 936, Hungary

\begin{abstract}
The extraordinary events of the last couple of years, like the surge and the topsy-turvy movement in oil, raw material and food prices, or the development of a so far unprecedented global financial and economic crisis, have been heavily testing the endurance of those earning their living from agriculture and related activities. All these troubles have not been beneficial to the ongoing trade liberalization process within the framework of WTO. Answers to the challenges at national level and the continuing proliferation of inter- and intraregional free trade agreements make the early global liberalization even less probable. The situation is further complicated by those really divergent changes of agricultural policy that are about to develop on the opposite sides of the Atlantic. In this paper, we describe the recent development of world's agricultural production and trade; offer an insight into the evaluation problems of worldwide food insecurity; and briefly compare the upcoming agricultural policy reforms in Europe and the US.
\end{abstract}

Keywords: Agricultural policy, agricultural and food production and trade, food security.

\section{INTRODUCTION}

Since the end of the first decade of this century, the media has become more and more inundated with reports and articles warning of growing hunger in the world, a joint consequence of rising demand in protein of some highly populated developing countries, the climate change with all its repercussions on agricultural production and prices, and a new spread of poverty and homelessness, as a by-product of the global financial and economic crisis. Since 1995-1997, the Food and Agriculture Organization of the United Nations (FAO) regularly reports on the growing number of the undernourished, with consolidated data for 2008 and estimates for 2009 and 2010 clearly above 900 million people. The total number of undernourished people in the world was even estimated to have reached more than 1000 million in 2009, and their proportion within the population of the developing countries to have risen again since 2008, the latter being not only a reversion of a decades' long tendency but also opposite to the Millennium Development Goal (MDG) target of halving the prevalence of undernourishment by 2015 [1].

Under such circumstances, it is interesting to examine whether developments in agricultural and food production and trade can explain such tendencies in world hunger, or if not, what could be the cause of the phenomenon.

*Address correspondence to this author at the Institute of World Economics, Centre for Economic and Regional Studies, Hungarian Academy of Sciences, Budaörsi út 45, 1112 Budapest, 1535 Budapest Pf. 936, Hungary; Tel: +361309-2643; Fax: +361-309-2624; E-mail: somai.miklos@krtk.mta.hu

\section{AGRICULTURAL PRODUCTION AND TRADE}

As one can clearly see from the image given by FAO statistics, world agricultural production - the net output, i.e. net of seed and feed costs - has continuously been increasing over the last 20 years (Figure 1). Moreover, this growth even speeded up in the second half of the period, which could be seen in the growing steepness of the diagram. Fortunately, this speeding up was faster in those regions where it was the most needed: in least developed and net food importing developing countries, while in Africa, the production growth rate could be maintained at a relatively high level for most of the period (Table 1). By contrast, in developed countries, and particularly in Europe, the production growth has been much slower for the whole period, due to differences in demographic path of the two worlds. Indeed, the agricultural sector, unlike the processing industry, is mostly driven by the internal demand (and the need for maintaining a certain level of security stock), and the world export market is rather viewed as residual market to absorb the redundant supply after the domestic demand has been satisfied. That's why world market prices for agricultural products are relatively low, as traders seek to getting rid of their perishable goods which cannot be stocked for long without degradation of quality.

From the aspect of food security, per capita rather than total agricultural production is of primary importance for the people (Figure 2 and Table 2). The best results were achieved by Asia and South-America, while the least developed and net food importing developing countries followed the world tendency. The same was true for Africa until 2006, but since then its 


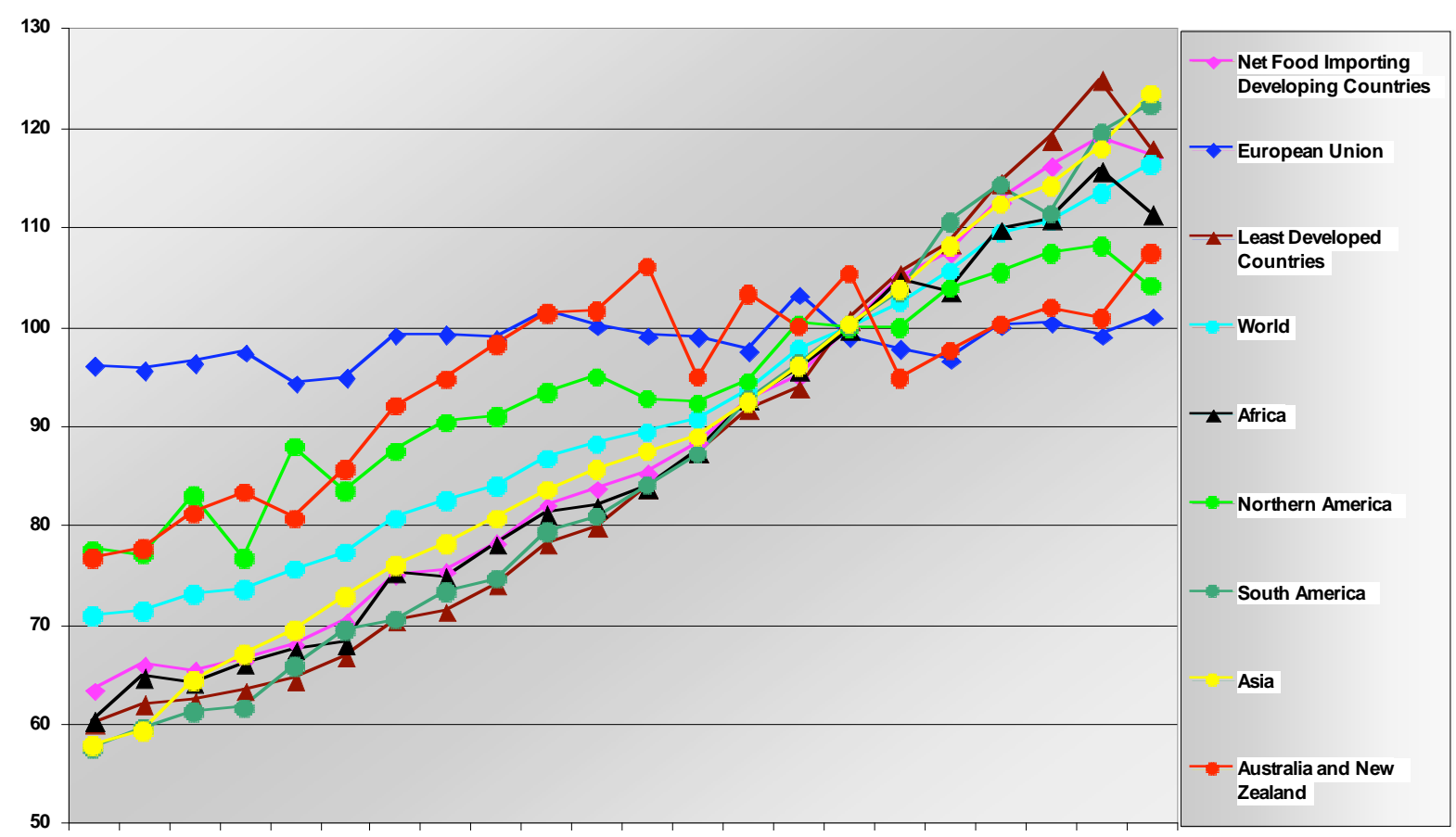

1990199119921993199419951996199719981999200020012002200320042005200620072008200920102011

Figure 1: Net Agricultural Production Index $(2004-2006=100)$.

Source: FAOSTAT [2]. FAO indices of net agricultural production testify the relative level of the aggregate volume of agricultural production for each and every year of the examined period in comparison with the base period of 2004-2006. The indices are based on price-weighted quantities after deductions have been made of products used as seed or feed.

Table 1: Changes of Net Agricultural Production Index (2004-2006 $=100)$, and Changes in Dynamics of Annual Average Changes in the First and Second Part of the Examined Period

\begin{tabular}{|c|c|c|c|c|c|c|}
\hline & $\begin{array}{c}2011 / \\
1990\end{array}$ & $\begin{array}{l}2000 / \\
1990\end{array}$ & $\begin{array}{l}2011 / \\
2001\end{array}$ & $\begin{array}{c}2000 / 1990 \text { av. } \\
\text { change } \\
\text { /year (A) }\end{array}$ & $\begin{array}{c}\text { 2011/2001 av. } \\
\text { change } \\
\text { /year (B) }\end{array}$ & $\mathbf{B} / \mathbf{A}$ \\
\hline European Union & $5.2 \%$ & $4.2 \%$ & $2.0 \%$ & $0.41 \%$ & $0.20 \%$ & $47.48 \%$ \\
\hline Least Developed Countries & $96.4 \%$ & $33.0 \%$ & $40.7 \%$ & $2.89 \%$ & $3.47 \%$ & $120.24 \%$ \\
\hline Africa & $84.6 \%$ & $35.8 \%$ & $32.8 \%$ & $3.11 \%$ & $2.88 \%$ & $92.49 \%$ \\
\hline Northern America & $34.2 \%$ & $22.5 \%$ & $12.3 \%$ & $2.05 \%$ & $1.16 \%$ & $56.86 \%$ \\
\hline South America & $112.2 \%$ & $40.4 \%$ & $45.5 \%$ & $3.45 \%$ & $3.82 \%$ & $110.81 \%$ \\
\hline Asia & $113.4 \%$ & $48.1 \%$ & $41.3 \%$ & $4.00 \%$ & $3.51 \%$ & $87.80 \%$ \\
\hline
\end{tabular}

Source: FAOSTAT [2]; av = average.

performance has been closer to that of the developed than that of the developing world. This change is very bad news for the continent with the world's fastest growing population. While in North-America, the decades-long increase in per capita production turned into stagnation, there is, since the end of the last century, a clear decreasing trend both in Europe and Australia. (In New Zealand, too, there has been some decline in per capita production since 2004, but much less than in Australia.) But, the causes of these negative trends are different: in Europe, it is the outcome of two-decades of efforts to curb overproduction of basic commodities like cereal, meat, milk and sugar; in Australia, it is increasingly due to climate change, i.e. more and more frequent and prolonged periods of drought. 


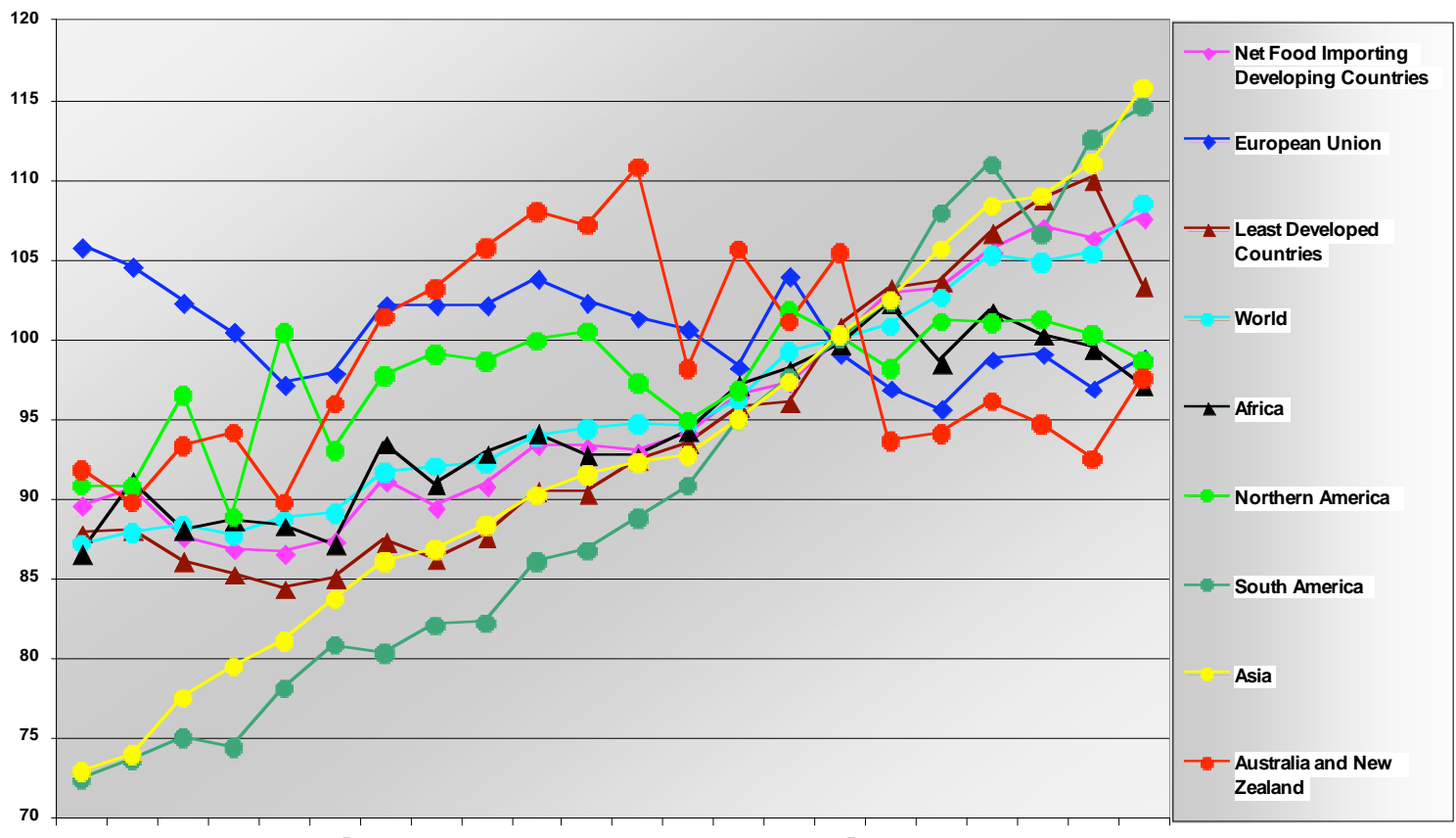

1990199119921993199419951996199719981999200020012002200320042005200620072008200920102011

Figure 2: Net Agricultural per capita Production Index $(2004-2006=100)$.

Source: FAOSTAT [2].

Table 2: Changes of Net Agricultural Production Index Per Capita $(2004-2006=100)$, and Changes in Dynamics of Annual Average Changes in the First and Second Part of the Examined Period

\begin{tabular}{|c|c|c|c|c|c|c|}
\hline & $\begin{array}{l}2011 / \\
1990\end{array}$ & $\begin{array}{l}2000 / \\
1990\end{array}$ & $\begin{array}{l}2011 / \\
2001\end{array}$ & $\begin{array}{c}\text { 2000/1990 av. } \\
\text { change } \\
\text { /year (A) }\end{array}$ & $\begin{array}{c}\text { 2011/2001 av. } \\
\text { change } \\
\text { /year (B) }\end{array}$ & $B / A$ \\
\hline European Union & $-6.6 \%$ & $-3.3 \%$ & $-2.5 \%$ & $-0.33 \%$ & $-0.28 \%$ & $84.94 \%$ \\
\hline Least Developed Countries & $17.7 \%$ & $2.9 \%$ & $11.8 \%$ & $0.29 \%$ & $1.25 \%$ & $434.56 \%$ \\
\hline Africa & $12.1 \%$ & $7.2 \%$ & $4.7 \%$ & $0.69 \%$ & $0.51 \%$ & $74.23 \%$ \\
\hline Northern America & $8.6 \%$ & $10.7 \%$ & $1.4 \%$ & $1.02 \%$ & $0.15 \%$ & $15.06 \%$ \\
\hline South America & $58.1 \%$ & $19.7 \%$ & $29.0 \%$ & $1.82 \%$ & $2.87 \%$ & $157.80 \%$ \\
\hline Asia & $58.9 \%$ & $25.6 \%$ & $25.5 \%$ & $2.30 \%$ & $2.56 \%$ & $111.12 \%$ \\
\hline
\end{tabular}

Source: FAOSTAT [2]; av = average.

It is to be noticed that 2008 CAP Reform known as "Health Check" decided on the termination of supply control measures in two of the main product groups: it abolished arable set-aside (in place since 1992) with immediate effect and started a gradual increase for milk quotas (in place since 1984) leading up to their abolition in 2015 (European Commission 2008) According to the agreement on the newest CAP reform, reached by the European Parliament, the EU Council of Ministers and the European Commission on late June 2013, sugar quotas will be abolished by 2017 [3].
Naturally, following the global tendencies, not only the agricultural production but also the trade of agricultural products has steadily increased. And this growth was even faster than that of the output: the volume of internationally traded agricultural goods has practically doubled during the last 15 years [4]. (This statement may probably be considered as an estimate since trade statistics in agricultural products, comparable to those on production, are not available on the FAO homepage. Researchers need to be content with data in value (Figure $\mathbf{3}$ and Table $\mathbf{3}$ ). 

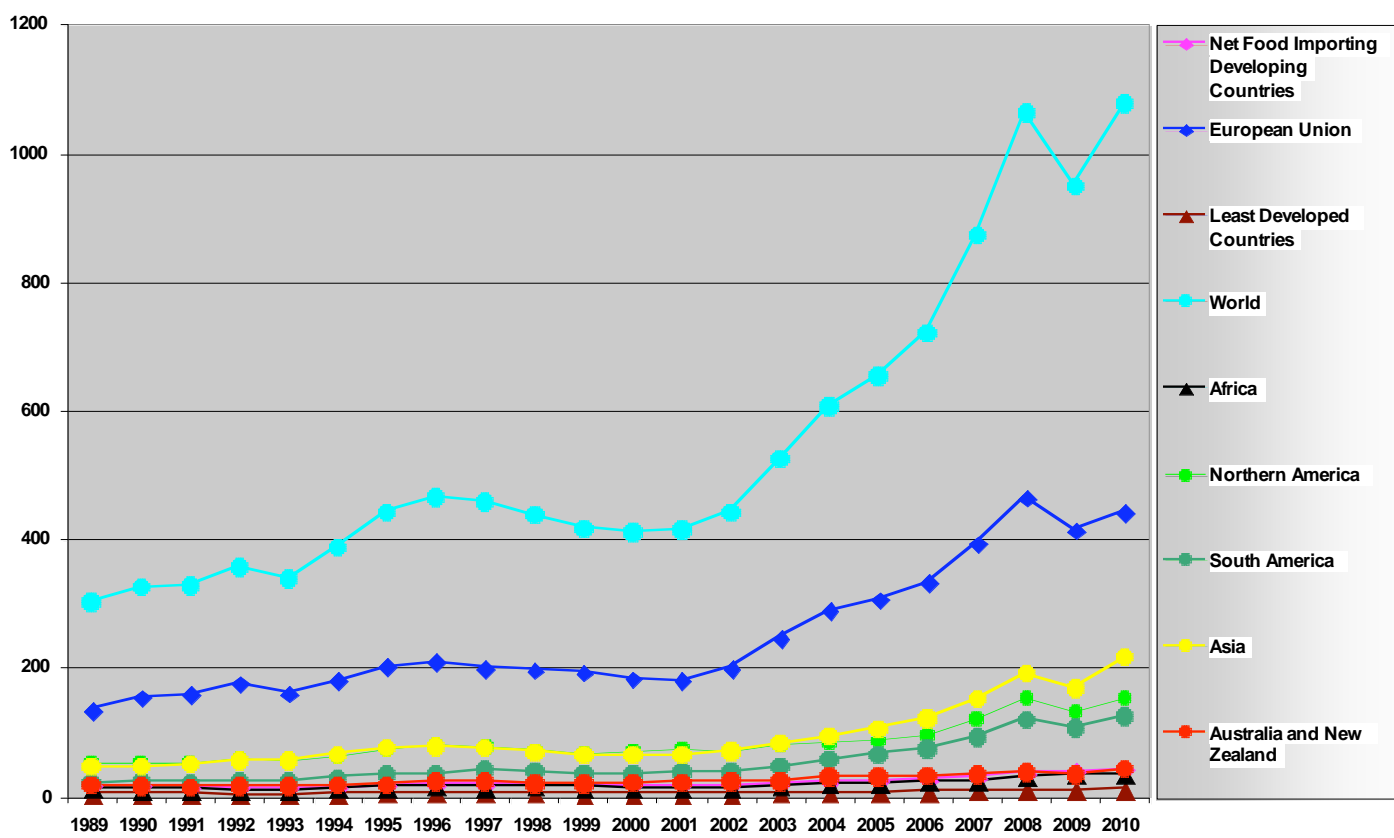

Figure 3: Agricultural Export Value (bn \$).

Source: FAOSTAT [5].

Table 3: Changes of Agricultural Export Value and Changes in Dynamics of the Changes Between the First and Second Part of the Examined Period

\begin{tabular}{|c|c|c|c|c|}
\hline & $\begin{array}{l}2010 / \\
1989\end{array}$ & $\begin{array}{c}1999 / \\
1989(A)\end{array}$ & $\begin{array}{c}2010 / \\
2000(B)\end{array}$ & $\mathbf{B} / \mathbf{A}$ \\
\hline Net Food Importing Developing Countries & 2.30 & 0.98 & 2.54 & 2.61 \\
\hline Least Developed Countries & 2.51 & 1.04 & 2.63 & 2.53 \\
\hline World & 3.57 & 1.38 & 2.62 & 1.90 \\
\hline Northern America & 2.95 & 1.29 & 2.13 & 1.64 \\
\hline South America & 5.92 & 1.69 & 3.68 & 2.17 \\
\hline Asia & 4.67 & 1.39 & 3.36 & 2.41 \\
\hline Australia and New Zealand & 2.48 & 1.15 & 2.02 & 1.76 \\
\hline
\end{tabular}

Source: FAOSTAT [5].

Nevertheless, from a comparison of charts describing the evolution of production (in volume) and those of trade flows (in value), some conclusions can be drawn. First, while data show an almost linear increase of the produced volumes, fluctuations are observed in trade values. Second, these fluctuations have recently become much more pronounced as a consequence of increased volatility in world food market prices. Third, as in the case of production, Asia and South America exhibited the fastest growth rates for exports, due to both their improving competitiveness and their abilities to make use of trade liberalisation fostered by the Uruguay Round Agreement on Agriculture.
As in the past twenty years, global trade rose much faster than production (both for agricultural and food products [6]), and production rose much faster than (world) population, the growth in per capita trade exceeded growth in per capita production. Hence, neither the increase in food prices nor a possible increase in the number of undernourished people can simply be explained by the shortage of supply. A certain precaution in wording is justified as FAO publications on undernourishment have until very recently suggested that, in spite of a continuous expansion of supply, the number of World hungry could not be prevented from rising since the mid 1990s (see 


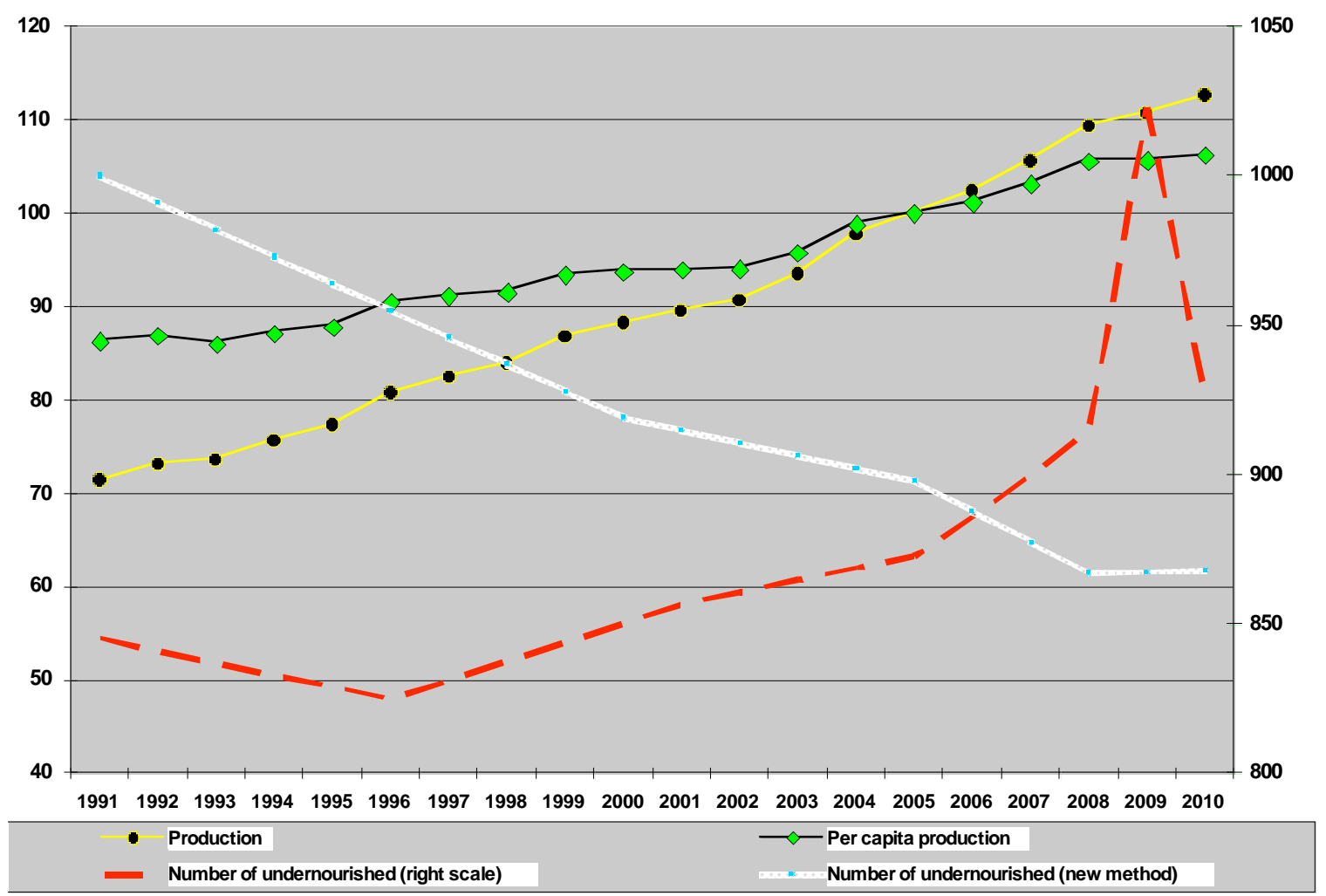

Figure 4: Changes in world net agricultural (global and per capita) production index (left scale, 2004-2006=100) and in number of undernourished people (million head, right scale).

Source: FAO [7,8,27,28]; FAOSTAT [2].

the red pecked line on Figure 4). This trend got even worse with the steep increase in food prices as of 2006 and the outbreak of world economic and financial crisis in 2008; these two phenomena together caused a reversal of a decades' long tendency of diminution of the proportion of the undernourished in the developing world $[7,8]$.

\section{WORLD HUNGER}

As a matter of fact, FAO data on hunger had generally been considered as reliable, since they fitted the empirical results. Obviously, it is no use to produce more and more food if it is not available to everyone. In the absence of sufficient demand, extra food can be turned into animal feed, industrial raw material or become waste. The quantitative development of production and the resulted food abundance in itself is no guarantee for complete food security even in the European Union. Table 4 shows that eating of meat, fish or a protein equivalent every second day is a problem for 6-7 per cent of the population in the old member states, and for every fifth people in the new ones.

What is true in Europe is true at global level too: the issue of food security cannot be reduced simply to a question of supply or production. In agriculture not only the quantity of production matters, but also the question of who produces for whom, at what prices and for how much profit. If developed countries try to overcome world hunger by increasing their own capacity and production, so without considering the interests of small-scale farming in developing countries, only hunger and malnutrition will increase [11]. Also, producing food and transporting it to countries suffering from hunger does not automatically result in a reduction of the number of undernourished. In order to provide food to consumers not only solvable demand but also transportation and storage infrastructure are necessary [12].

Concerning the aggravation of hunger, one cannot avoid mentioning the responsibility of international trade. It is well known that since the 1980s, a huge number of developing countries have turned from net exporters to net importers of food, a phenomenon in which subsidised exports from both Europe and the US played an important role. First, by spending a lot of money on both direct and indirect export subsidies, the European integration and the United States almost triggered a trade war against each other for the world agro-food markets. Then, during the GATT Uruguay 
Table 4: Hardship and Risk of Poverty in the New Members of the EU

\begin{tabular}{|c|c|c|c|c|c|c|c|}
\hline & \multicolumn{3}{|c|}{$\begin{array}{l}\text { Inability to afford a meal with meat, } \\
\text { chicken, fish }\end{array}$} & \multicolumn{4}{|c|}{ At risk of poverty/social exclusion } \\
\hline & \multicolumn{6}{|c|}{$\%$ of total population } & \multirow{2}{*}{$\begin{array}{c}\text { In Millions } \\
2011\end{array}$} \\
\hline & 2005 & 2008 & 2011 & 2008 & 2010 & 2011 & \\
\hline Bulgaria & 29.6 & 43.2 & 50.8 & 38.2 & 41.6 & 49.1 & 3.7 \\
\hline Latvia & 23.4 & 26.8 & 30.8 & 33.8 & 38.1 & 40.1 & 0.9 \\
\hline Hungary & 26.1 & 27.6 & 29.0 & 28.2 & 29.9 & 31.0 & 3.1 \\
\hline Slovakia & 29.2 & 23.0 & 23.2 & 20.6 & 20.6 & 20.6 & 1.1 \\
\hline Lithuania & 19.1 & 23.2 & 23.0 & 27.6 & 33.4 & 23.5 & 0.2 \\
\hline Romania & 19.2 & 21.3 & 21.8 & 44.2 & 41.4 & 40.3 & 8.6 \\
\hline EU 12 (new MS) & 20.6 & 20.0 & 20.5 & 31.2 & 30.2 & 30.5 & 31.4 \\
\hline Croatia & $:$ & 15.7 & 16.9 & n.a. & 31.3 & 32.7 & 1.4 \\
\hline Poland & 20.7 & 15.5 & 14.1 & 30.5 & 27.8 & 27.2 & 10.2 \\
\hline Czech Republic & 12.2 & 9.7 & 10.7 & 15.3 & 14.4 & 15.3 & 1.6 \\
\hline Estonia & 5.3 & 10.1 & 10.4 & 21.8 & 21.7 & 23.1 & 0.3 \\
\hline Slovenia & 12.0 & 8.5 & 10.4 & 18.5 & 18.3 & 19.3 & 0.4 \\
\hline EU 27 & 9.4 & 8.7 & 9.7 & 23.5 & 23.4 & 24.2 & 119.6 \\
\hline EU 15 & 6.5 & 5.8 & 6.9 & 21.4 & 21.6 & 22.1 & 88.2 \\
\hline
\end{tabular}

Source: Eurostat $[9,10]$.

$\mathrm{a}=$ Or vegetarian equivalent every second day.

Round, they arrived at a compromise (Blair House Agreement) which practically excluded other GATT contracting parties from agricultural discussion, and exempted the major part of the EU and US market support measures (i.e. the compensatory payments of 1992 CAP reform and the deficiency payments of the US farm bill, both of them working as indirect export subsidies) from the obligation of gradual reduction [13]. The increasing quantity of cheap import food which invaded the local markets made it impossible for indigenous farmers to continue with their own production and forced them to leave and seek nonagricultural/urban jobs. As cities, however, cannot provide employment for everyone, a significant share of the immigrant population only increased the number of those living in slums.

It is less known that the developed countries may increase misery and hunger in the third world not only by their cheap food exports but also by their expanding food imports. As a result of decades-long bargaining process with the United States - with such milestones like the Dillon Round of GATT (1960-61) where the EU made momentous concessions by having granted zero tariff on major feedstuffs, and the Blair House Agreement (1992) in which the EU committed itself to self-limitation of its planted area with oilseeds - protein crops currently occupy only 3 per cent of EU's total arable land and production meets only 20 per cent of demand [14]. European feed manufacturers have increasingly been replacing locally produced cereals and protein crops with cheap imports of soya and other feedstuffs from mainly North and South Americas. The imports of soya alone require more than 19 million hectares to be cultivated abroad, roughly 40 per cent of the total virtual land import of the EU. The largest areas planted with soya for European feed consumption are located in Brazil and Argentina where about three quarters of the EU soybean and soybean meal imports originate, but the neighbouring countries (especially Paraguay) also play an increasing role as suppliers.

In 2010, 68 per cent of EU soybeans imports came from South America (45\% from Brazil, 17\% from Paraguay, $4 \%$ from Uruguay, $2 \%$ from Argentina) and 30 per cent from North America (21\% from the USA, $9 \%$ from Canada). As far as the origins of EU soybean meal imports are concerned, the share of South America was even higher (93\% of which $51 \%$ for Argentina, $42 \%$ for Brazil), while that of the USA was 5 per cent [15].

Thanks to the modern technology (i.e. pesticideintensive cultivation of genetically modified soya 
endangering soils, water and human health), the business of vegetable protein production does not require large manpower resources. In the middle of the 2000s, in Brazil, soya occupied 8 times higher share in planted area than in agricultural employment, while in Argentina the extremely mechanised production model only needed 2 full-time workers for 1,000 hectares of land [16]. Lands and production are concentrated in the hands of ever fewer investors and farm operators. The majority of the crop is grown in large monocultures from where, in several cases because of lack of secure land titles, rural families have been expelled. What is worse, only a minority of them can find job on the plantations, others have to move further into the forests, thereby increasing deforestation, breaking virgin ground, overgrazing sensitive meadows, or migrate into cities, where they soon get familiar with misery and hunger. So, the expansion of soybean plantation in South America has not only significant ecological but also social price.

Other possible factors that might have been contributed to rising food prices, and consequently to rising world hunger in the last couple of years, are:

a rapid change in demand, especially the growing consumption of meat in newly industrialising countries and the growing share of energy crops in agricultural production; the impact of some external factors, like rising oil price, the devaluation of US dollar and the widespread recourse to trade barriers (e.g. exports restrictions and taxes) as a reaction of many stages to the rapidly rising food prices;

Finally, the increasing speculation in futures markets.

Although Halder [17] demonstrated that, with the exception of the last mentioned factor (i.e. speculation, identified as the primary cause for high food prices), all others could only partly explain the extent of the price rise, large group of experts found FAO's data about growing world hunger credible and compatible with their own experiences. As these experiences showed that, with the globalisation process gaining momentum, not only the developing but also the developed countries had been experiencing rising differences in living standards between people. Many of the losers of this process got unemployed, lost their homes, plunged into poverty and hunger. This trend had only been amplified by the combined effects of repeated food crisis (since 2006/2008) and the financial and economic crisis (since 2008). Moreover, to explain the contradiction between abundant food supply and pervasive hunger, i.e. between growing (total and per capita) food production (and trade) and the rising number of undernourished, both the expanding use of

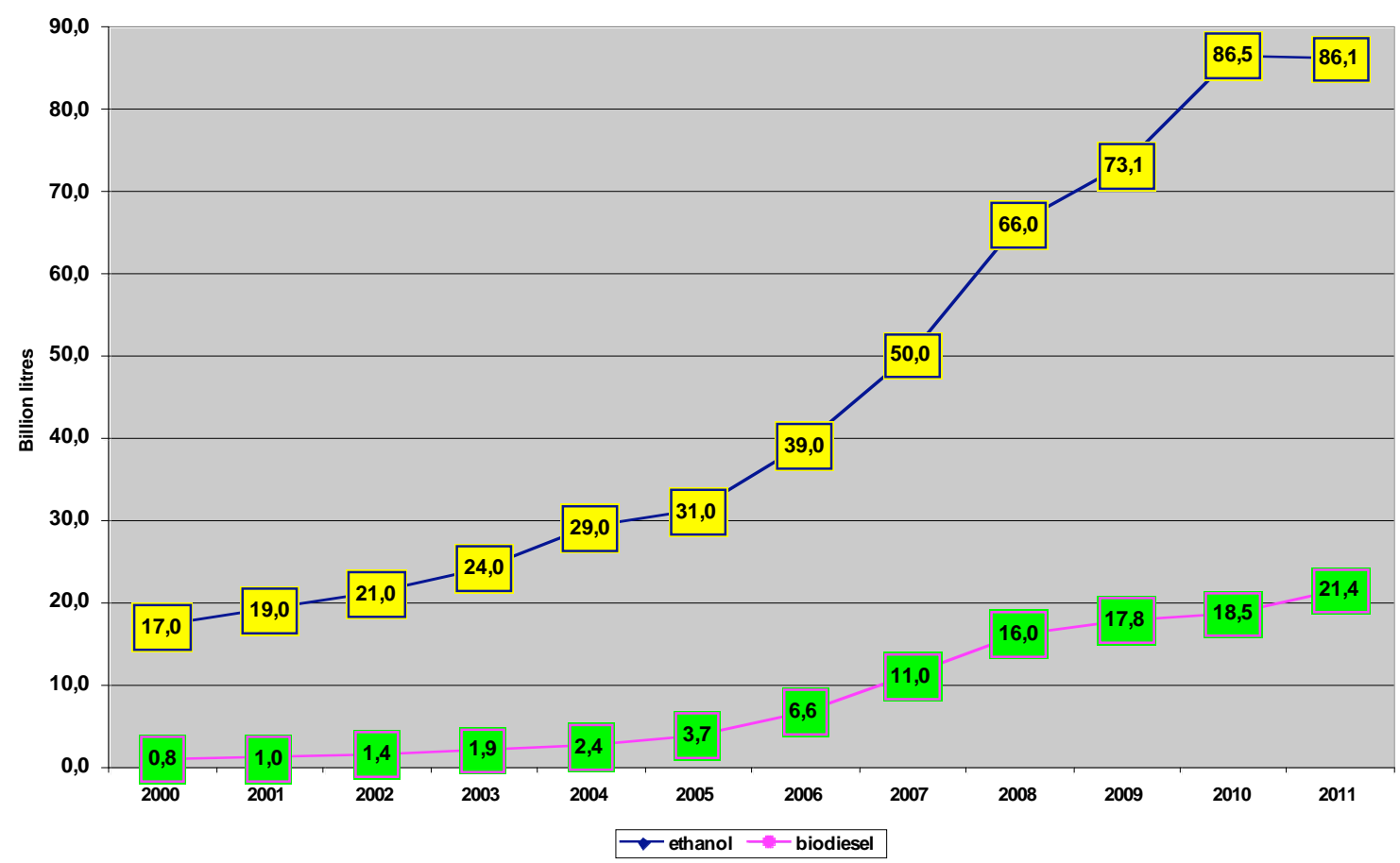

Figure 5: World ethanol and biodiesel production, 2000-2011.

Source: REN21 [19]. 
agricultural products (and land) for energy and the increasing meat consumption of China (and other fastgrowing countries) seemed to be logical answers.

Here, two comments are necessary. First, although crop grown for biofuels utilise around 1 per cent of agricultural land [18], it is a rapidly developing business: between 2000 and 2010 world production of ethanol increased by more than 5 times, that of the biodiesel by more than 20 times (Figure 5). Nowadays, there is more and more criticism about biofuel production for consuming too much freshwater [20] and inducing probably as large or larger land use change emissions than projected GHG emissions savings could stem from using biofuels as a substitute for fossil fuels [21]. Second, although China has been able to meet the rising food demand on home market from its own booming agro-business, soybean is a notable exception the imports of which may have the same devastating effects on small farmers in exporting countries as in the case of EU soya imports $[22,23]$.

\subsection{Assessment of Undernourishment}

As far as the world's millions of hungry people are concerned, first, for 2009 and 2010, FAO published estimates which were based not on its own data and methodology but on those of United States Department of Agriculture Economic Research Service (USDA ERS) [24]. However, from the data available until 2008, it can be clearly seen that, after 1995, the number of starving people has increased steadily (see the red pecked line on Figure 4). Moreover, in stark contrast to the hunger alleviation goals set in the Millennium Development Goals (MGDs) of the United Nations, which dates back to the Millennium Summit of 2000 and the target $1 \mathrm{C}$ is about to halve, between 1990 and 2015 , the proportion of the people of the world who suffer from hunger [25], a reversal of a long tendency of diminution of the proportion of the undernourished in the developing world did appear in 2008 [26].

Later on, in its issue "The State of Food Insecurity in the World 2011" the FAO announced that an effort was under way to review its methodology for estimating undernourishment. With 2011 being a year of transition, updated estimates for the number of hungry people in 2009 and 2010 were not reported, nor had an estimate been made for 2011 [27]. Finally, the 2012 issue revealed that the experts in FAO had, over the two previous years, not only overhauled the methodology used to estimate hunger, but also rewritten ("improved" by the official terminology) the estimates of the number and hence the proportion of undernourished people going back to 1990 (see the white descending line in Figure 4). This kind of changing data retroactively for 20 years has had two important consequences: first, the trend in the number of hungry people, which for most of the period (namely, from 1995 to 2009), was clearly ascending became clearly descending; second, any expert analyses based on historical data became invalid. The rules of the formal logic have been restored: Figure 4 shows that when the world is able to produce more food, the number of hungry people is decreasing, and when food production (as a result of world crisis after 2007) is stagnant, the decline in the number of undernourished also comes to a halt.

There is one more very important consequence of the change in methodology and the recalculation of data: efforts undertaken all over the world to reduce hunger yielded better results than previously believed, thus, against the expectations based on old FAO statistics, the MDG target of halving the prevalence of undernourishment in the developing world by 2015 could be within reach (Table 5 and Figure 6). The data generated from the reassessment put the undernourishment estimate for developing countries at 23.2 percent of the population in the base period (1990-92), which implies a new MDG target of 11.6 per cent for 2015. If the pace of the annual average decline of the past 20 years could be maintained, the prevalence of hunger, by the calculation of the FAO, would decrease to 12.5 percent by 2015 , still above the (new) target, but much closer to it than previously hoped for [28].

It is worth noting that FAO's calculation of its undernourishment indicator for 2015, the above mentioned $12.5 \%$, is likely to be based on a very simple statistical estimate, as if the experts simply laid their ruler across the graph (see the blue line of linear trend in Figure 6) Although nothing is mentioned about the method in FAO's report, there is high chance a linear regression was used to make projections for 2015. In case we disregard the fact that in today's difficult times of global economic and financial crisis, the use of a polynomial trend would have certainly been more appropriate (see the green pecked line in Figure 6), estimates for 2015 could have also been calculated from trends based on the annual average decline over either the period from 1990-92 to the last years for which data were available, i.e. 2010-2012 (see column " $A$ " in Table 5 and the yellow line in Figure 6), or the period from 1990-92 to the last years for 
Table 5: Prevalence of Hunger, Progress Towards MDG Target (-50\%) and Estimates for 2015

\begin{tabular}{|c|c|c|c|c|c|c|c|}
\hline \multirow[t]{2}{*}{$\begin{array}{l}\text { Proportion of undernourished } \\
\text { in total population (\%) }\end{array}$} & \multirow{2}{*}{$\frac{1990-92}{X}$} & \multirow{2}{*}{$\frac{2007-09}{Y}$} & \multirow{2}{*}{$\frac{2010-12^{*}}{Z}$} & \multirow{2}{*}{$\begin{array}{l}2010-12^{*} \\
\text { millions }\end{array}$} & \multirow{2}{*}{$\begin{array}{c}\text { Change so far } \\
(\%)\end{array}$} & \multicolumn{2}{|c|}{$\begin{array}{l}\text { Estimates } \\
\text { for } 2015\end{array}$} \\
\hline & & & & & & A & B \\
\hline Developed countries & 1.9 & 1.3 & 1.4 & 16.0 & -26.3 & 1.32 & 1.11 \\
\hline Developing countries & 23.2 & 15.5 & 14.9 & 852.0 & -35.8 & 13.64 & 13.13 \\
\hline Western Asia & 6.6 & 9.4 & 10.1 & 21.0 & 53.0 & 11.00 & 10.87 \\
\hline Southern Asia & 26.8 & 18.8 & 17.6 & 304.0 & -34.3 & 16.18 & 16.25 \\
\hline Eastern Asia & 20.8 & 11.8 & 11.5 & 167.0 & -44.7 & 10.21 & 9.34 \\
\hline South-Eastern Asia & 29.6 & 13.2 & 10.9 & 65.0 & -63.2 & 8.93 & 9.47 \\
\hline
\end{tabular}

Source: FAO [28] (p. 9.) + the author's own estimates for $2015,{ }^{*}$ projections (as indicated by FAO).

base year $=1990-1992 \Rightarrow 1991=X$

last year for which consolidated data are available $=2007-2009 \Rightarrow 2008=Y$

last year for which data are available $=2010-2012 \Rightarrow 2011=Z$

1.year $(1992)=X * q$

hypothesis $=$ smooth change over time $(q)$

$\Rightarrow 2$ year $(1993)=X * q * q=X * q^{2}$

$\Rightarrow 17$.year $(2008)=Y=X * q^{17} \Rightarrow q=\sqrt[17]{\frac{Y}{X}}$

$\Rightarrow 20$ year $(2011)=Z=X * q^{20} \Rightarrow q=\sqrt[20]{\frac{Z}{X}}$

forecast for the 21. year $(2012)=Z * q$

forecast for the 24.year $(2015)=A=Z * q^{4}=Z * \sqrt[20]{\frac{Z}{X}}$

by the same token:

forecast for the 18.year $(2009)=Y * q$

forecast for the 24.year $(2015)=B=Y * q^{7}=Y * \sqrt[17]{\frac{Y}{X}^{7}}$

$A=\left(\sqrt[20]{\frac{Z}{X}}\right)^{4} * Z$ and $B=\left(\sqrt[17]{\frac{Y}{X}}\right)^{7} * Y$

which consolidated data are available, i.e. 2007-09 (see column "B" in Table 5 and the pink line in Figure 6). The existence of the B-pillar in Table 5 is justified by the fact that data for 2010-12 are only projections. As it is clearly demonstrated by Table 5 and Figure $\mathbf{6}$, the rate of 12.5 percent for prevalence of hunger in developing world projected by FAO for 2015 is by far the most optimistic estimate.

Changes in methodology are justified by FAO, on the one hand, by the improvement of the assessment techniques (e.g. more detailed and more accurate statistics being available on demography and anatomy, as well as improved parameters for dietary energy requirements, etc.), by a better access to household survey data on food consumption for a range of countries and by new country-specific estimates of food losses. On the other hand, the old methodology did not capture the impact of short-term price spikes and other economic shocks, unless these were reflected in changes in long-term food consumption patterns. As far as economic downturns are concerned, for many developing countries (i.e. China, India or Indonesia), global shocks were less pronounced and resulted in milder slowdown in GDP growth and smaller increase in staple food prices than thought before [29]. It is true, however, that considerable differences among countries and regions remain: while in Latin-America and the eastern and southern parts of Asia substantial progress in the reduction of hunger has been achieved, the opposite holds true for Western Asia (Table 5). Anyhow, global trends took a 180 degree turn as data referring to overall changes at the beginning of the period had to be corrected upwards and those of recent years downwards (see the red and the white lines in Figure $\mathbf{4}$ and data in Figure 7).

From Figure 7 it appears that for three out of the five categories of data (namely population size, food supply and methodology) the use of updated values 


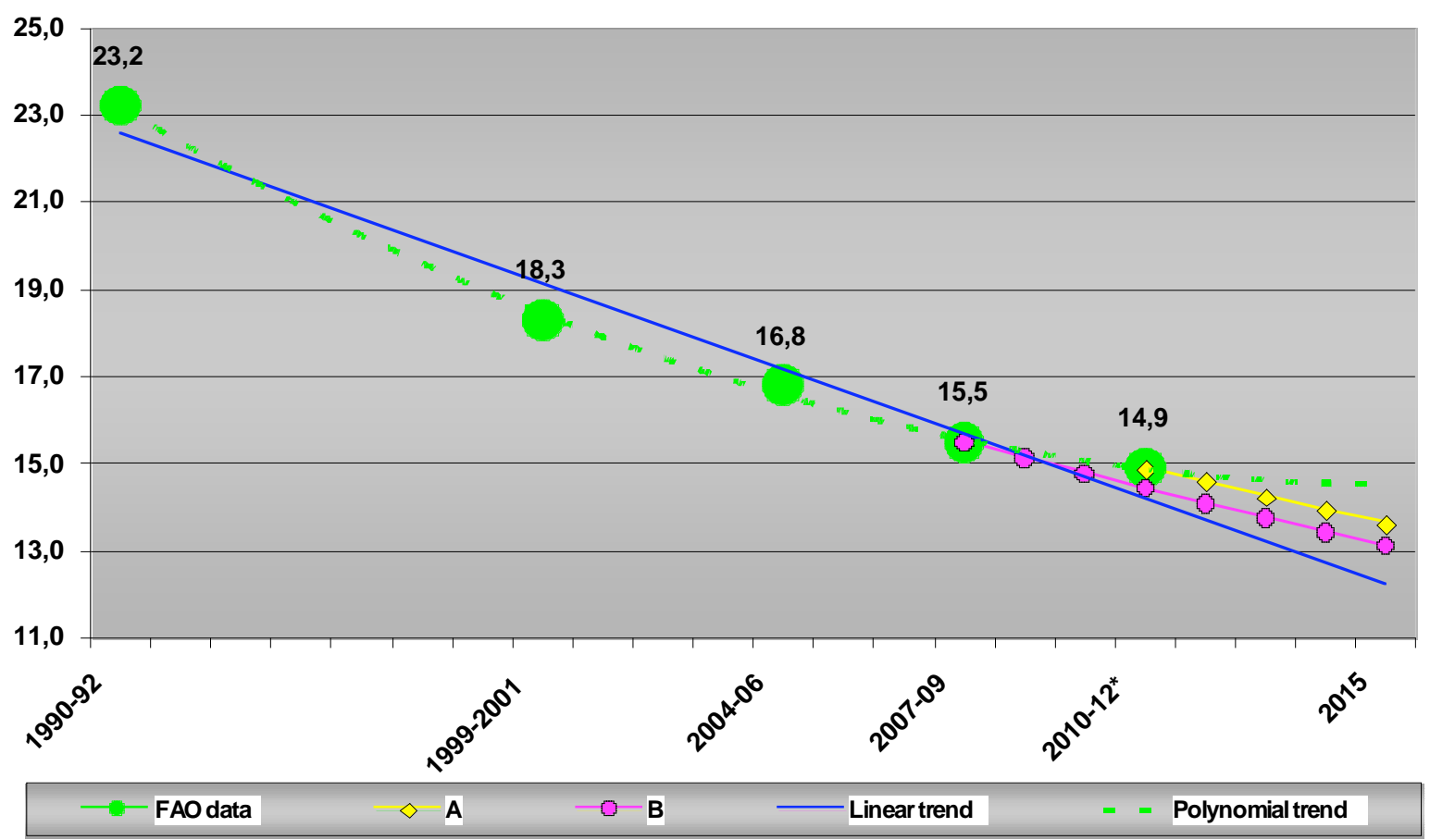

Figure 6: Prevalence of undernourishment in developing world. (Proportion of undernourished in total population (\%)). Source: FAO [28] in addition to the author's own estimates for A and B (for method see Table 5).

${ }^{*} \mathrm{FAO}$ data for 2010-12 are projections.

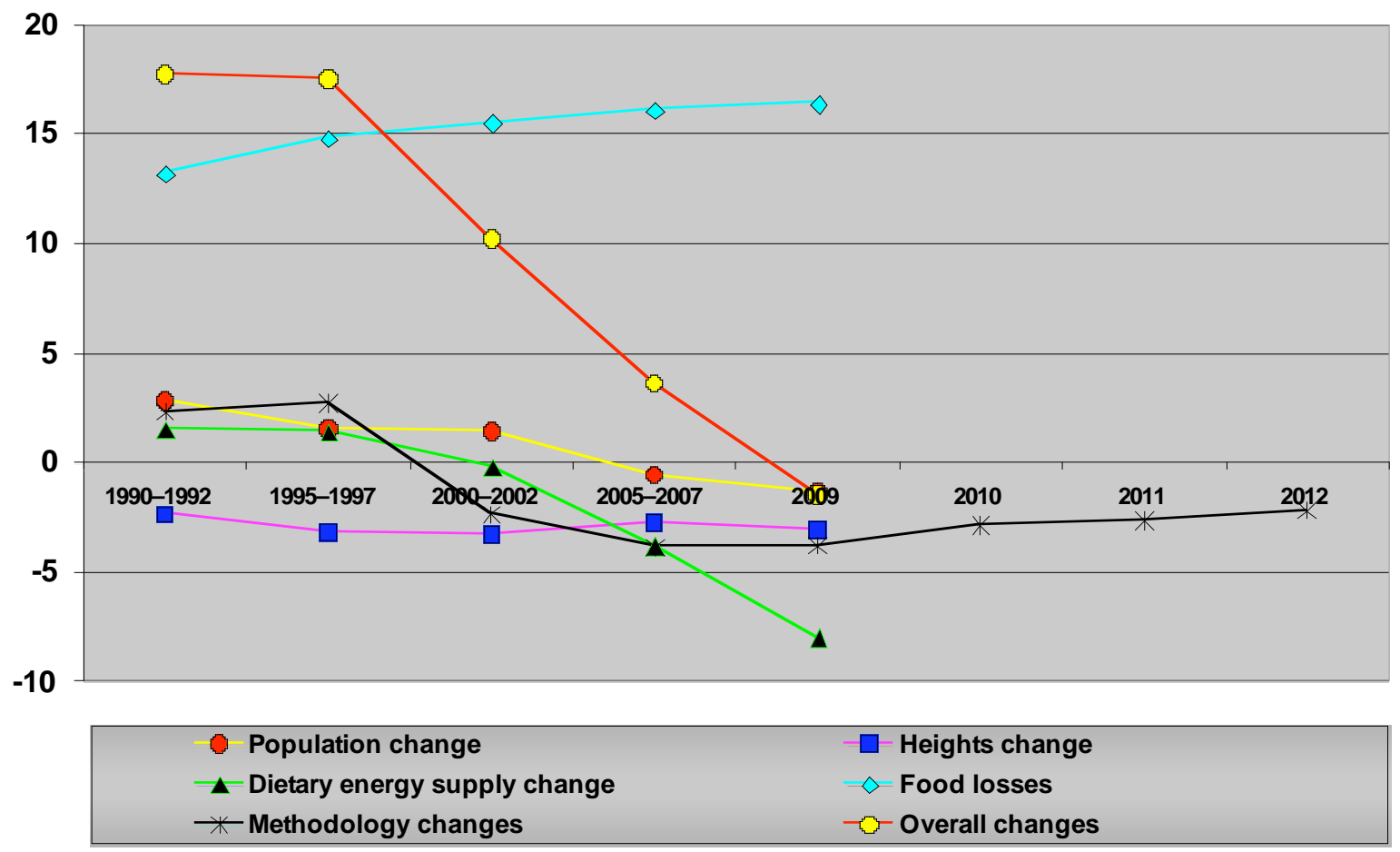

Figure 7: Impact of data and methodology revisions on FAO estimates of the number of undernourished population in developing regions (\%).

Source: Table A 2.1 in FAO [28].

resulted, at the beginning of the scrutinised period, in an increase in the estimated number of undernourished, and then, lately, in a reduction in it. As far as the data on people's physical stature (heights) are concerned, their (downward) revision resulted in an approximately constant reduction in the estimated 
number of hungry people over the entire period. Although the updates of the above mentioned four data sets, taken one by one, do not cause important annual (percentagewise) changes on FAO's estimates - the only exception being the impact of food supply change for $2009(-8 \%)$ - their combined impact would, in theory, result in a sharply falling trend line with more than 20 percentage points of difference between the two end dates of the period. But there is a fifth element, food losses, which may be significant during retail distribution and storage and which, of all revisions, is the one that causes the most dramatic change in FAO's estimates on hunger: its impact shows a slightly ascending trend (see the pale blue line in Figure 7) departing from +13.2 per cent in 1990-92 and culminating at +16.4 percent in 2009 , which moderates somewhat the steepness of the trend line caused by the other four elements. It's a pity, these high-impact estimates of food losses are, according to FAO's own words, "still tentative" and "based on rough regional aggregates" [30].

Finally, how to evaluate FAO's efforts and proceedings to improve its estimates? Refining and developing the methodology of data collection can only be welcome; moreover, it should also be an inherent part of any statistical production process spanning over many years. However, changing data retroactively is always a delicate affair. Even more so for twenty years, as the further we go back in time, the more it becomes difficult to gather information to support the change. Anyhow, the change created a new situation, and brought about a huge task for the analysts to reconsider the statements and to re-evaluate the conclusions that had so far been drawn from the old data set.

If we examine FAO's new estimates on hunger together with data on agricultural (and food) production and trade, the least we can say that it was worth to produce more food as the number of the undernourished has, against all previous reports based on the old data set, steadily decreased for the last two decades. This is especially good news for the developed (e.g. EU) countries where supporters of the current new/old trends in agricultural policy (i.e. the one with a focus on production and productivity growth) seem to have gained a bit of legitimacy; their aspirations can now be aligned with the Millennium Development Goals. So, there will be a strong argument to preserve the traditionally high level of public subsidies for European (and other rich countries') agriculture, - a support which has, for the last more than fifty years, been transformed into farmers/owners movable and immovable property. Reforms towards a cheaper and more liberal system of agricultural policy are likely to be stopped or watered down, thus land owners, especially those in no way associated with farming, should not be afraid of a sudden drop of value of their properties.

\section{AGRICULTURAL POLICY IN THE EU AND THE US VERSUS WORLD HUNGER}

As it was already mentioned, the world's most developed regions - especially the EU and the US are directly responsible, through their agricultural and trade policies, for the worsening of the quality of life of millions of small farmers, and indirectly for the persistence of unacceptably high levels of hunger in developing countries. Both in the EU and the US, despite decades of reforms, agricultural policy continues to favour a relatively small number of highly rationalised big farms and export-oriented food processors. The reason for this lies in the fact that there is a continuous pressure on the policy-makers to increase the international competitiveness of the agrofood business by providing traders and processors with cheap agricultural raw materials.

The main difference in methods used on the two sides of the Atlantic is schematically illustrated on Figure 8: while in Europe since the 1992 reform, the dominant part of subsidies (i.e. CAP direct payments) have been paid to farmers regardless of need or market conditions, so even at a time of high prices and record market income, in America, farm support has always had a pronounced counter-cyclical character, making most of the support available only when commodity markets drop in order to counteract low farm prices. The latter method is somewhat cheaper which is not surprising as in the US, the average size of the professional farms is, for several reasons, much bigger than in Europe; so, due to economies of scale, production is more efficient and fewer subsidies are needed. The damage done to the developing countries by US farm policy is, however, comparable to that caused by European common agricultural policy, for, after all, what matters are the artificially low producer prices which obviously would be higher if farmers could not rely on public subsidies. These low prices then destroy the subsistence farming, hence indirectly contributing to hunger and poverty all around the developing world.

Interestingly enough, in 2013, new agricultural policy reforms are under discussion in the US and in 


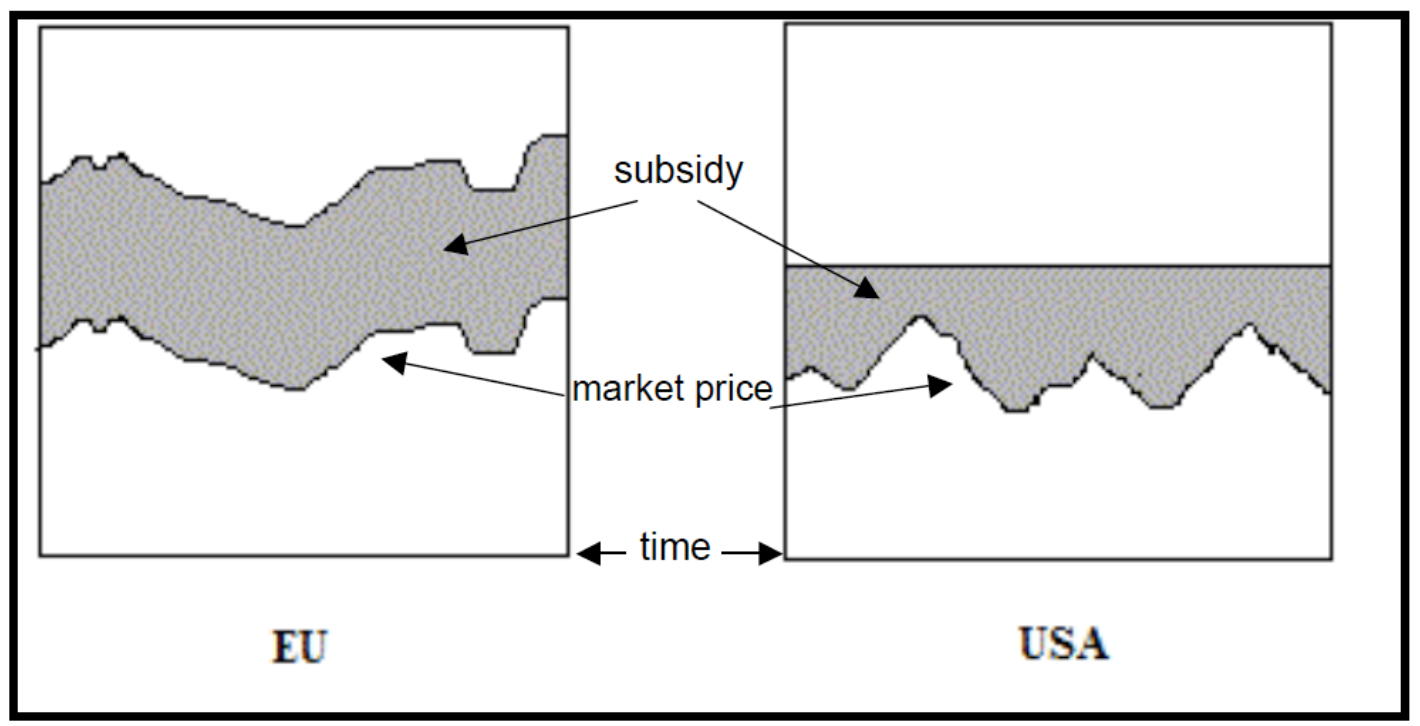

Figure 8: Agricultural policy in the EU and the US: Simplistic models of the policies based on the author's own experiences in the field of both EU and US agricultural policies since 1992 [13].

Europe. Although there is an obvious determination of the decision makers to move away from the current systems, in that distribution of public support among farmers and regions could be less inequitable in the future, but this move is either a result of a need to cut public deficit (in the case of the US) or is mitigated by the fact that most of the changes are optional (in the case of the EU).

In the Unites States, because of a disagreement between the two chambers of the current legislature, the latest 2008 farm bill, which was set to expire at the end of 2012, has been approved for partial extension through September 30, 2013. In the meanwhile both chambers took up separate farm bills proposals. The House version failed to pass on June 20, 2013, while that of the Senate (known as the Agriculture Reform, Food and Jobs Act of $2013-$ S. 954; $113^{\text {th }}$ Congress) passed the Senate with an overwhelming bipartisan majority of 66-27 on June 10, 2013 and has got the support of President Obama. If the bill passes the House, it could replace the current bill, known as Food, Conservation and Energy Act of 2008 [31]. The new bill eliminates and streamlines numerous programs, and strengthens crop insurance and other risk management approaches, saving taxpayers USD 23 billion over the period of 2014-2023. A large part of the saving comes from capping payments under the so-called commodity programs $(\$ 50,000$ per entity) and excluding anyone with an adjusted gross income of more than $\$ 750,000$ from receiving commodity programs' benefits [32].

In the European Union, a political agreement was reached on 26 June 2013 by the Commission, the
Council and the European Parliament on the reform of the common agricultural policy focusing on challenges of food security, sustainable use of natural resources and growth. While the money available under market measures and direct payments will be reduced by more than 17 per cent in real terms vis-à-vis to current Multiannual Financial Framework (MFF), its distribution among members, regions and farmers seem to have a chance to become more equitable $[33,34]$. What could lessen the amplitude of changes, however, is the fact that several schemes (like the Small Farmers Scheme, the redistributive payments for the first hectares or the scheme for Areas with Natural Constraints/Less Favoured Areas) redirecting support towards smaller and weaker farms or regions remain optional for the member states [35]. Also, there is risk in transferring too much subsidies from the big to the small farms: if an EU country went too far on this path, it could disadvantage its professional farmers, undermine their resilience compared to their European competitors and eventually put them in danger of going bankrupt, as it is clearly seen in intra-sectoral debates over the issue [36].

\section{CONCLUSIONS}

In this paper, we tried to assess the recent development of world's agricultural production and trade and shed some light on the problematic of evaluation of food insecurity. We also intended to offer a brief insight into upcoming agricultural reforms in the European Union and the United States. As far as the relationship between world agro-food production/trade and hunger is concerned, we can conclude that neither 
the increase in food prices nor a possible increase in the number of undernourished people can simply be explained by the shortage of supply. As a matter of fact, in the past twenty years, global trade rose much faster than production, and production rose much faster than (world) population. Concerning the upcoming reforms in the EU and the US, they can be considered as the first cautious steps in the right direction, in that distribution of public support among farmers and regions could be less inequitable in the future. People need to see, however, that these changes are certainly not driven by developed countries' anxiety about developing countries subsistence farming. There are other factors at work instead, like the need for reducing public spending which make these changes inevitable, and the persistence of high food (and farm-gate) prices which make them possible. On both sides of the Atlantic, bearing responsibility for food security remains at not only national but also international level, and hence the necessity of improving competitiveness for home producers continue to fit into the strategic goals of the agricultural policy. Anyway, the above depicted change in FAO's estimation method on hunger changing data retroactively for 20 years and turning the formerly ascending trend of the number of undernourished into a clearly descending one provides justification to the supporters of a strong agricultural policy (i.e. with a focus on production and productivity growth), as their aspirations can now be aligned with the Millennium Development Goals. The author of this paper tends to agree with those (e.g. the experts of such organisations like Via Campesina, an international movement defending small-scale sustainable agriculture against corporate driven agriculture and transnational companies $[37,38]$ who claim the right of the developing countries to make everything to improve and reach their self-sufficiency in major food staples and to control the marketing of their products. A comprehensive overhaul of the agricultural policies in developed countries could improve chances for the long-term sustainability of both social and natural environment for agriculture throughout the developing world. Thus, global food security could be significantly enhanced.

\section{ACKNOWLEDGEMENTS}

This paper is based on studies made by the author during his participation to both the OTKA-project No. K82034, entitled "World economic dimensions of food security" co-ordinated by Judit Kiss, and the "World economy report' project of IWE in 2012.

\section{REFERENCES}

[1] FAO, WFP. The state of food insecurity in the world 2010 addressing food insecurity in protracted crises. WFP, FAO 2010; pp. 8-9. http://www.fao.org/docrep/013/i1683e/ i1683e.pdf

[2] FAOSTAT (web). Production. http://faostat.fao.org/site/612/ DesktopDefault.aspx?PagelD=612\#ancor

[3] European Commission. Political agreement on new direction for CAP. Commission, Press Releases Rapide, 26/06/2013. http://europa.eu/rapid/press-release_IP-13-613_en.htm

[4] Csáki C. Where the world's agriculture is heading for? Changing priorities in world agricultural production. Gazdálkodás 2012: 56(2): 103-117.

[5] FAOSTAT (web). Trade. http://faostat.fao.org/site/342/ default.aspx

[6] Somai M. How the new common agricultural policy can help to improve global nutrition? In: Kiss J, Ed. Global economy dimensions of food security, IWE-CERSHAS, OTKA Budapest 2013; ISBN 978-963-301-595-7, pp. 27-56. http://www.vki.hu/news/news_594.html?setlang=english

[7] FAO, WFP. The state of food insecurity in the world 2009, Economic crisis - impacts and lessons learned. WFP, FAO 2009; ISBN 978-92-5-106288-3. ftp://ftp.fao.org/docrep/fao/ 012/i0876e/i0876e.pdf

[8] FAO, WFP. The state of food insecurity in the world 2010 , addressing food insecurity in protracted crises. WFP, FAO Roma 2010; ISBN 978-92-5-106610-2. http://www.fao.org/ docrep/013/i1683e/i1683e.pdf

[9] EUROSTAT. At risk poverty or social exclusion in EU27. Eurostat News Release; Stat/12/171 3 December 2012. http://europa.eu/rapid/press-release_STAT-12-171_en.htm

[10] EUROSTAT (web). Inability to afford a meal with meat, chicken, fish (or vegetarian equivalent) every second day. http://appsso.eurostat.ec.europa.eu/nui/show.do?dataset=ilc _mdes03\&lang=en

[11] De Schutter $O$. The common agricultural policy towards 2020: The role of the European Union in supporting the realization of the right to food; Comments and recommendations by the UN Special Rapporteur on the right to food. 17.06.2011. http://www.iatp.org/files/CAP\%20 Reform\%20Right\%20to\%20Food.pdf

[12] Kiss J. Is there anything to be celebrated? MTA VKI Short Notice 2010; 208. http://www.vki.hu/sn/sn_208.pdf

[13] Somai M. Chances of the Hungarian agriculture in the light of negotiations for EU-accession. PhD theses, SZIE Gödöllö 2002. http://szie.hu/file/tti/archivum/SomaiM_phd.pdf

[14] Euractiv.com. MEPs want to end 'protein deficit' for EU livestock. 10 March 2011 http://www.euractiv.com/cap/mepswant-protein-deficit-eu-liv-news-502925

[15] MVO Nederland. Fact sheet soy. Product Board MVO, August 2011. http://www.mvo.nl/LinkClick.aspx?fileticket= $\mathrm{dZc7cde} 2 \mathrm{~b} 5 \mathrm{~s} \% 3 \mathrm{D} \& \mathrm{tabid}=756 \& \mathrm{mid}=4234 \&$

[16] Fritz T. Globalising hunger: food security and EU's Common agricultural policy (CAP). 14 November 2011; ISBN 978-3923020-55-3, FDCL-Verlag Berlin. http://www.tni.org/sites/ www.tni.org/files/cappaperfinal-web.pdf

[17] Halder G. The Food Crisis of 2008: The Debate on its Causes and Connections with the Financial Crisis. Die Erde 140 2009(2) Miscellaneous Issues pp. 127-153.

[18] IEA. World energy outlook 2008. International Energy Agency. ISBN 978-92-64-04560-6. p. 163. http://www.iea. org/media/weowebsite/2008-1994/WEO2008.pdf

[19] REN21. Renewables 2012 - global status report. Renewable Energy Policy Network for the $21^{\text {th }}$ Century. http://www.map. ren21.net/GSR/GSR2012_low.pdf 
[20] IEA. World energy outlook 2012, Executive summary. http://www.iea.org/publications/freepublications/publication/E nglish.pdf

[21] Kretschmer B. The land-use implications of EU bioenergy policy - going beyond ILUC. Institute for European Environmental Policy (IEEP), January 2011. http://www.ieep. eu/assets/750/Policy_briefing_ILUC_21_01_2011_FINAL.pdf

[22] USDA. World agricultural supply and demand estimates", USDA ERS FAS WASDE August 10, 2012. http://www.usda. gov/oce/commodity/wasde/latest.pdf

[23] USDA. Livestock and poultry: World markets and trade, USDA FAS October 2003; April 2012. http://usda01.library. cornell.edu/usda/fas/livestock-poultryma//2000s/2003/ livestock-poultry-ma-10-01-2003.pdf \& http://www.fas.usda. gov/dlp/circular/2012/livestock_0412.pdf

[24] FAO, WFP. The state of food insecurity in the world 2010, addressing food insecurity in protracted crises. WFP, FAO Roma 2010; ISBN 978-92-5-106610-2. http://www.fao.org/ docrep/013/i1683e/i1683e.pdf

[25] UN web. We can end poverty 2015 - A Gateway to UN System's Work on the MDGs - Goal 1: Eradicate extreme poverty and hunger. United Nations (UN). http://www.un.org/ millenniumgoals/poverty.shtml

[26] FAO, WFP. The state of food insecurity in the world 2010, addressing food insecurity in protracted crises. WFP, FAO Roma 2010; ISBN 978-92-5-106610-2. http://www.fao.org/ docrep/013/i1683e/i1683e.pdf

[27] FAO, WFP. The state of food insecurity in the world 2011, How does international price volatility affect domestic economies and food security? IFAD, WFP, FAO Roma 2011; ISBN 978-92-5-106927-1. http://www.fao.org/docrep/014/ i2330e/i2330e.pdf

[28] FAO, WFP and IFAD. The State of Food Insecurity in the World. Economic growth is necessary but not sufficient to accelerate reduction of hunger and malnutrition. Rome, FAO 2012; ISBN 978-92-5-107316-2. http://www.fao.org/docrep/ 016/i3027e/i3027e.pdf

[29] FAO, WFP and IFAD. The State of Food Insecurity in the World. Economic growth is necessary but not sufficient to accelerate reduction of hunger and malnutrition. Rome, FAO
2012; ISBN 978-92-5-107316-2. http://www.fao.org/docrep/ 016/i3027e/i3027e.pdf

[30] FAO, WFP and IFAD. The State of Food Insecurity in the World. Economic growth is necessary but not sufficient to accelerate reduction of hunger and malnutrition. Rome, FAO 2012; ISBN 978-92-5-107316-2. http://www.fao.org/docrep/ 016/i3027e/i3027e.pdf

[31] US Senate Committee on Agriculture. Agriculture reform, food and jobs act of 2013. US Senate Committee on Agriculture, Nutrition and Forestry. http://www.ag.senate.gov/ issues/farm-bill

[32] US Senate Committee on Agriculture. Agriculture reform, food and jobs act of 2013. US Senate Committee on Agriculture, Nutrition and Forestry (web) Summary (p. 1.) http://www.ag.senate.gov/issues/farm-bill

[33] Somai, Miklós. EU-budget: less money, less Europe? The new MFF seen from the new member states perspective. Unia Europejska 2013; 218(1): 13-21.

[34] European Council. Conclusions (Multiannual Financial Framework), Brussels, 8 February 2013, EUCO 37/13, CO EUR 5, CONCL 3. http://www.consilium.europa.eu/uedocs/ cms_data/docs/pressdata/en/ec/135344.pdf

[35] European Commission. Political agreement on new direction for CAP Commission, Press Releases Rapide, 26/06/2013. http://europa.eu/rapid/press-release_IP-13-613_en.htm

[36] The Telegraph (web). Row with farmers over plans to redirect subsidies to wildlife. 18 July 2013. http://www.telegraph.co. uk/earth/countryside/10188767/Row-with-farmers-over-plansto-redirect-subsidies-to-wildlife.html

[37] Via Campesina. The right to produce and access to land Food sovereignty: A future without hunger. http://www. voiceoftheturtle.org/library/1996 Declaration of Food Sovereignty.pdf

[38] Via Campesina. The International Peasant's Voice. Organisation. What is La Via Capmesina, 09 February 2011. http://viacampesina.org/en/index.php/organisationmainmenu-44/what-is-la-via-campesina-mainmenu-45

Received on 15-11-2013

Accepted on 18-11-2013

Published on 31-12-2013

\section{DOI: http://dx.doi.org/10.6000/1927-3037.2013.02.04.5}

(c) 2013 Miklós Somai; Licensee Lifescience Global.

This is an open access article licensed under the terms of the Creative Commons Attribution Non-Commercial License (http://creativecommons.org/licenses/by-nc/3.0/) which permits unrestricted, non-commercial use, distribution and reproduction in any medium, provided the work is properly cited. 